\title{
Design, Development and Performance Evaluation of Manually Operated Two Row Trolley Type Vegetable Transplanter
}

\author{
P.V. Thorat ${ }^{1^{*}}$, K.B. Jhala ${ }^{2}$ and M.L. Jadhav ${ }^{3}$ \\ ${ }^{1}$ CAET, JAU, Junagadh- 362001, India \\ ${ }^{2}$ CIAE, Nabi bagh, Bhopal- 462038, India \\ *Corresponding author
}

\author{
A B S T R A C T
}

\begin{tabular}{|l|}
\hline K e y w o r d s \\
Vegetable \\
transplanter, Age of \\
seedlings, Types of \\
bed, Cost of operation, \\
Field efficiency.
\end{tabular}

\section{Introduction}

Agriculture is the backbone of Indian economy. Today, India ranks second worldwide in farm output. About 175 types of vegetables are grown in India, produce $14 \%$ (146.55 million tons) of world's vegetables and have $15 \%$ (8.5 million hectares) of world's area under vegetables. Productivity of vegetables in India $(17.3 \mathrm{t} / \mathrm{ha}$ ) is less than the world average productivity (18.8 t/ha) in 2013-2014. Seeds of the crops like cowpea, okra, carrot etc. are either drilled or planted directly. However, most of the vegetable crops like tomato, onion, chilli, brinjal, cauliflower, cabbage etc. are transplanted.
Transplanting is practice which involves the placing of seedlings either on the ridge or well prepared seedbed, such that they starts establishing their roots and survive as a separate plant. Seedlings for transplanting purposes are raised on beds in which seeds are broadcasted or dibbled in lines. According to the requirement of the procedure followed for transplanting of a particular crop or method. Seedling are then uprooted manually when they are about 4-10 weeks old and transplanted in fields (Choudhury et al., 2001). Transplanting of seedling is a manual and labour-intensive operation. Timely 
transplanting of vegetable crops is essential for higher yields. A survey conducted to access mechanization gaps in the seeding, planting and transplanting of vegetable crops indicated that Indian vegetable growers expressed desire for a low cost vegetable transplanter (Choudhury et al., 1997). The average vegetable growers in India mainly belong to small and medium category of farmers.

These farmers need a vegetable transplanter that is simple in design, affordable and suitable for their farming conditions. Considering the small and fragmented holdings under vegetable crops and to avoid bending posture in manual transplanting, it was considered that manually operated vegetable transplanter will be suitable for adoption in Indian conditions.

\section{Materials and Methods}

\section{Determination of agronomic requirement for transplanting vegetable seedlings}

The agronomic requirement for a particular crop includes time of transplanting, spacing and preparation of bed required for transplanting of that crop etc. The field was prepared until the soil tilth was fine. Then beds were formed using bed former. The recommended dimensions of seed bed were $90 \mathrm{~cm}$ top width, $120 \mathrm{~cm}$ bottom width and average height was about $20 \mathrm{~cm}$ suggested by agronomist.

\section{Determination of the morphological parameters of seedlings}

The easy passage of plug seedlings through seedling delivery tubes without getting stuck and its subsequent vertical placement along with the movement from the jaw is influenced by the physical properties seedlings such as canopy diameter, plant height etc.

\section{Plant height}

The seedlings were gently pulled from the plug tray and length of the plant (tip of the leaf to the end of stem i.e. excluding roots) was measured by scale. Ten such observations were recorded for every age (i.e. 4, 5 and 6 weeks of seedlings).

\section{Canopy of plant}

Canopy can be defined as the extent to which the vegetation is spread out in horizontal direction for a plant. Randomly selected ten plants were used to measure canopy of plant for each case by means of vernier callipers having least count of $0.01 \mathrm{~mm}$. The spread out is of great importance as the dimensions of the delivery tubes are to be decided on these value.

\section{Design of manually operated two row trolley type vegetable transplanter}

The design criterions for the functional components were kept as lowest, simple design and highly user friendly in nature. The conceptual design of transplanter is shown in Figure 1 with its different functional components. The main components of the designed transplanter are as main frame, hollow delivery tube, jaw, foot lever, hand lever, tray platform and wheels.

\section{Main frame}

It was main part of the transplanter served as base of the transplanter on which other parts were fixed. The main frame was made up of galvanized iron square pipe size $25 \times 25 \mathrm{~mm}$. The height of main frame is kept such that a general male can work without unnecessary stretching or bending for operating the controls and that to with ease. The main frame is supporting structure to delivery tubes of vegetable transplanter. The overall dimension of main frame is $60 \mathrm{~cm} \times 40 \mathrm{~cm} \times 80 \mathrm{~cm}(\mathrm{~L} \times$ 
$\mathrm{W} \times \mathrm{H})$. The height of main frame was $80 \mathrm{~cm}$ for maintaining the height of trolley as 100 $\mathrm{cm}$, to minimize the energy required to push during work. The length of main frame was $60 \mathrm{~cm}$ for accommodating seedling tray, decided on the basis of functional grip reach of male operator (i.e. $75.07 \mathrm{~cm}$ ). The width of frame was $40 \mathrm{~cm}$ for accommodating seedling trays on the tray platform which was made on main frame.

\section{Hollow delivery tube}

The hollow delivery tube was made up of galvanized iron pipe having diameter of $7 \mathrm{~cm}$. The hollow delivery tubes are used to pass the seedlings to the bed. The length of hollow delivery tube was $60 \mathrm{~cm}$ and fitted in tube holder. The opening mechanism consisting of two jaws at the bottom of the delivery tube and a hand lever to open these jaws was provided. Tube holder is mounted on the mainframe such that it can be lowered by means of foot lever. At the bottom of the delivery tube a mechanism is provided for allowing seedling to be dropped in the hole punched by the vertical downward movement of the tube into the soil bed. Two slots diagonally opposite to each other were made on the delivery tube. The extended link to operate the actuator ring was taken out from slot. The marker made up of $6 \mathrm{~mm}$ stainless steel round bar was fitted on front of hollow delivery tube for marking the position of the next plant.

\section{Actuator ring}

Actuator ring was provided inside the hollow delivery tube at the bottom end and connected to hand lever for opening of jaw. The actuator ring was made up of galvanized iron pipe of diameter $6.75 \mathrm{~cm}$ and length $10 \mathrm{~cm}$, such that it can move up and down easily inside a delivery tube having $7 \mathrm{~cm}$ of diameter. At the middle portion of a ring two numbers of bar (2 cm length, $6 \mathrm{~mm}$ diameter) were welded diagonally opposite to each other and both were extended at right angle up to a length of $50 \mathrm{~cm}$ which were once again connected to a hand lever for lowering and raising the ring for opening and closing of the jaws. By pressing the hand lever, the actuator ring moves vertically downward and forces the two halves of jaw to move them apart so as to place the seedling in the hole created by the movement of jaw.

Jaw

The jaw is main operational part of vegetable transplanter which actually penetrates the soil and makes space for dropping seedling in the bed. The Jaw was made up using of hollow pipe of galvanized iron. The diameter of pipe was $7 \mathrm{~cm}$, keeping in mind the general height of seedling the height of jaw was kept as 20 $\mathrm{cm}$. The pipe was cut such that when actuator ring was operated by a lever both the jaws (two halves) were separated apart and a path was open for seedling to pass through. The springs are provided around the jaws to bring back the jaws to its original position i.e. closed jaws. A spring having $10 \mathrm{~mm}$ outer diameter and 40 active coils made out of 1 $\mathrm{mm}$ diameter stainless steel wire was used for bringing the jaws back to its original position on relieving the pressure by means of a hand lever.

\section{Levers}

\section{Foot lever}

As the name suggests it is the lever operated by a foot to lower down the delivery tubes as and when required. The foot lever was fitted on horizontal rod of $40 \mathrm{~cm}$ length. The length of foot lever from the horizontal rod was 80 $\mathrm{cm}$ fitted at an angle of $56^{\circ}$ with horizontal. The inclined foot lever was joined to vertical square pipe of $1.5 \mathrm{~cm} \times 1.5 \mathrm{~cm}$. The height of foot lever $72 \mathrm{~cm}$. The bottom end height of foot lever from ground was $30 \mathrm{~cm}$. The foot 
lever was made up of galvanized iron square pipe size $1.5 \mathrm{~cm} \times 1.5 \mathrm{~cm}$. The foot lever was fitted with spring and fixed with front end of frame. The spring having $2 \mathrm{~mm}$ wire diameter, $15 \mathrm{~mm}$ outer diameter and 85 active coils was fitted. The extensions were made up of galvanized iron square pipe size $1.5 \mathrm{~cm} \times$ $1.5 \mathrm{~cm}$. The length of extension from main frame was $35 \mathrm{~cm}$. The holes of $14 \mathrm{~mm}$ were made on extensions at $5 \mathrm{~cm}$ gap for fitting of delivery tube. The support of $6 \mathrm{~mm}$ thick flat bar was provided between these two extension. The length of support was $30 \mathrm{~cm}$.

\section{Hand lever}

The function of the hand lever is to open jaw in the soil bed. Readily available grip was used. Both the right as well as left side levers were located in between two delivery tubes and that too within easy reach of an operator. Since the movement of delivery tube was to be made relative to the frame a set of levers were provided on both the sides. In a set, one lever was fixed and other was operative.

The size of fixed lever was $10 \mathrm{~cm}$ and other was $13 \mathrm{~cm}$, both were made out of galvanized iron square pipe of $1.5 \mathrm{~cm} \times 1.5 \mathrm{~cm}$. The levers were spaced apart to provide movement of $8 \mathrm{~cm}$. The mechanism was attached to the delivery tube such that it allows the movement of actuator ring inside the delivery tube through appropriate linkage.

\section{Tray platform}

In general the plug tray used for the vegetable crop like chilli available in the market is of 50 cells having dimensions as $520 \mathrm{~mm} \times 280$ $\mathrm{mm}$. So as accommodate the tray, the platform for same was kept as $500 \mathrm{~mm} \times 400$ $\mathrm{mm}(\mathrm{L} \times \mathrm{W})$. The platform for carrying seedling trays was made of MS sheet $(3 \mathrm{~mm}$ thick). It was welded on the main frame.

\section{Dead weight stand}

The stand was made to put some dead weight on front side of frame, for avoiding lifting of machine during operation specially while pressing foot lever. The stand was made up of galvanized iron square pipe $1.5 \mathrm{~cm} \times 1.5 \mathrm{~cm}$. The length of folding stand was $30 \mathrm{~cm}$ and width was similar to main frame (i.e. $40 \mathrm{~cm}$ ) of machine. The galvanized iron square pipe was welded at $15 \mathrm{~cm}$ interval length wise.

\section{Handle}

$\mathrm{C}$ shaped handle was made using two galvanized iron square pipes $1.5 \mathrm{~cm} \times 1.5 \mathrm{~cm}$ of $105 \mathrm{~cm}$ length and one pipe of length 30 $\mathrm{cm}$. They were joined by means of welding. Now the open end of handle was welded on front side of the bottom of the frame. The welding was made such that the closed end was near to rear end of the top of the frame. So as to avoid the lifting of machine from the rear side, a handle was provided such that the force applied at from the rear side acts somewhere near front wheels and whole of the transplanter moves ahead by application of force on that handle.

\section{Wheels}

The four rubber wheels were provided for ease of transport in field having $20 \mathrm{~cm}$ diameter and $5 \mathrm{~cm}$ thickness. The wheels were fitted with clamp and welded to the main frame. The height of clamp was $15 \mathrm{~cm}$ and width of clamp was $7 \mathrm{~cm}$. The clamp was made up of $6 \mathrm{~mm}$ thick flat bar.

\section{Field Performance Evaluation}

To evaluate the machine for its performance, it was tested rigorously in the actual field condition. The developed vegetable transplanter was evaluated in terms of field capacity, field efficiency, labour requirement, 
cost of operation and other performance parameters such as upright plants, laying down plants and plant mortality.

\section{Upright plants (\%)}

Planting angle is the angle of inclination of the plant with the vertical. The plants having planting angles of $0^{\circ}$ to $30^{\circ}$ were considered as likely to produce upright plants (Boa, 1984). Planting angle was measured for twenty seedlings in each replication.

\section{Laying down plants (\%)}

Plants standing at less than $30^{\circ}$ with the horizontal plane were considered as laying down plants. Laying down plants out of twenty seedlings were noted in each replication and the percentages of laying down plants were calculated.

\section{Plant mortality (\%)}

Number of seedlings transplanted and survived after 20 days of transplanting in fivemeter row length were noted for four different replication in experimental plot and percentage plant mortality was calculated.

\section{Field capacity and field efficiency}

Measuring the width of coverage, speed and actual time of operation, theoretical field capacity, effective field capacity and field efficiency were calculated.

\section{Cost economics}

The total hourly cost of operation was determined based on fixed cost and variable costs. It was converted into cost required for transplanting of 1000 seedlings, by dividing it with the number of seedlings transplanted per hour and was expressed in ₹ /1000 seedlings. The cost of manual transplanting was also observed and calculated for comparison. Payback usage and payback period were also worked out.

\section{Comparative field performance of developed transplanter}

The developed two-row manually operated vegetable transplanter was compared with manual method for its economic feasibility and subsequent acceptability by vegetable growers. Field capacity, plant mortality and cost economics for both developed transplanter and manual method of transplanting were calculated.

\section{Statistical analysis}

The statistical analysis was carried out according to Factorial Randomized Block (FRBD) Design (Panse and Sukhatme, 1967).

\section{Results and Discussion}

The morphological parameters like plant height and canopy of seedlings were studied for chilli seedlings and are given in following table 2 .

Field performance evaluation of the vegetable transplanter

The results of the experiments for chilli seedlings were analyzed according to Factorial Randomized Block (FRBD) Design.

\section{Uprights plants}

The percentage of upright plants varied from 66.25 to $75 \%$. Table 5 shows that the mean upright plants for all three ages were significant. It also shows that the values of upright plants were higher at the middle age of seedlings i.e. 5 weeks. Table 5 shows that the mean values of upright plants for two types of bed were non-significant. The 
interaction between age of seedling and type of bed on upright plants was found nonsignificant at 5 per cent level of significance. The higher value of upright plants $(75 \%)$ in mulch bed may be due to moisture that is present in mulch bed creates the favourable environment for plants survival.

\section{Laying down plants}

The percentage of laying down plants varied from 25 to $33.75 \%$. Table 5 shows that the mean layed down plants for all three ages were significant. It also shows that the values of laying down plants were least at the middle age of seedlings i.e. 5 weeks. Table 5 shows that the mean values of laying down plants for both types of bed were non-significant. It also shows that on mulch bed, laying down plants were least. The interaction between age of seedling and type of bed on laying down plants was found non-significant at 5 per cent level. The value of laying down plants $(25 \%)$ is low in case of 5 weeks age and this is reverse as that in case of upright plants. The reason seems to the availability of moisture for longer duration provides favourable environment for plants survival.

\section{Plant mortality}

The percentage of plant mortality varied from 13.75 to $40 \%$. Table 5 shows that the mean plant mortality for all three ages was significant. It also shows that the value of plant mortality was least at the middle age of seedlings i.e. 5 weeks. Table 5 shows that the mean plant mortality for two types of bed was significant. It also shows that on mulch bed, plant mortality was least $(13.75 \%)$. This was because plastic mulches are used in summer and they reflect heat, causing a reduction in soil temperature. Since plastics are impervious to water, soil water will not evaporate, significantly reducing water loss.
Plastic mulch greatly reduces weed competition resulting in a healthier crop on the mulch bed as compared to bare bed.

\section{Theoretical field capacity}

The values of theoretical field capacity varied from 0.01445 to $0.01716 \mathrm{ha} / \mathrm{h}$. Table 5 shows that the mean theoretical field capacity for all three ages was significant. It also shows that the value of theoretical field capacity was higher at the 6 weeks $(0.01716 \mathrm{ha} / \mathrm{h})$ age of seedlings. As the age of seedling increases the strength of seedling as well as the bonding of roots and soil is firm, due to which the handling becomes easy and less time consuming. Therefore the theoretical field capacity, were higher in 6 week seedlings as compared to 5 week and 4 week seedlings. Table 5 shows that the mean theoretical field capacity for both types of bed was significant.

It also shows that on mulch bed, theoretical field capacity were higher for all the ages of seedlings. The interaction between age of seedling and type of bed on theoretical field capacity was found non-significant at 5 per cent level. It clearly states that as the age increases the value of theoretical field capacity increases in both types of beds.

\section{Effective field capacity}

The values of effective field capacity varied from 0.01254 to $0.01444 \mathrm{ha} / \mathrm{h}$. Table 5 shows that the mean effective field capacity for all three ages was significant. It also shows that the value of effective field capacity was higher at the 6 weeks $(0.01444 \mathrm{ha} / \mathrm{h})$ age of seedlings. As the age of seedling increases the strength of seedling as well as the bonding of roots and soil is firm, due to which the handling becomes easy and less time consuming. 
Table.1 Transplanting time and spacing required for chilli

\begin{tabular}{|l|l|l|l|}
\hline Sr. No. & Crop & Time of transplanting & Spacing $(\mathbf{c m} \times \mathbf{c m})$ \\
\hline 1. & Chilli & $\begin{array}{l}\text { January - February } \\
\text { June - July } \\
\text { September - October }\end{array}$ & $60 \times 45$ \\
\hline
\end{tabular}

Table.2 Plant height of seedlings

\begin{tabular}{|c|c|c|c|}
\hline \multirow{2}{*}{ Morphological parameter } & \multicolumn{3}{|c|}{ Chilli Seedling } \\
\cline { 2 - 4 } & \multicolumn{3}{|c|}{ Age of seedling, weeks } \\
\cline { 2 - 4 } & $\mathbf{4}$ & $\mathbf{5}$ & $\mathbf{6}$ \\
\hline Plant height, $\mathbf{m m}$ & $50.4 \pm 3.41$ & $67.4 \pm 2.98$ & $36 \pm 3.44$ \\
\hline Canopy of seedling, $\mathbf{m m}$ & $28.25 \pm 1.37$ & $30.70 \pm 0.89$ & 1.31 \\
\hline
\end{tabular}

Table.3 Observed field parameters

\begin{tabular}{|c|c|c|c|c|c|c|}
\hline \multirow{3}{*}{ Field parameters } & \multicolumn{5}{|c|}{ Chilli Seedling } \\
\cline { 2 - 7 } & \multicolumn{4}{|c|}{ Age of seedling, weeks } \\
\cline { 2 - 7 } & \multicolumn{2}{|c|}{$\mathbf{4}$} & \multicolumn{2}{c|}{$\mathbf{5}$} & \multicolumn{2}{c|}{ 6 } \\
\cline { 2 - 7 } & Mulch bed & Bare bed & Mulch bed & Bare bed & Mulch bed & Bare bed \\
\hline Moisture content, \% & 14.05 & 13.07 & 14.37 & 13.62 & 13.54 & 12.82 \\
\hline Bulk density, g/cc & 1.112 & 1.120 & 1.086 & 1.110 & 1.110 & 1.119 \\
\hline
\end{tabular}

Table.4 Comparative field performance of developed transplanter and manual transplanting for chilli seedlings

\begin{tabular}{|c|l|c|c|c|c|}
\hline $\begin{array}{c}\text { Age of } \\
\text { seedling }\end{array}$ & Parameters & $\begin{array}{c}\text { Mortality } \\
(\boldsymbol{\%})\end{array}$ & $\begin{array}{c}\text { Effective field } \\
\text { capacity (ha/h) }\end{array}$ & $\begin{array}{c}\text { Labour } \\
\text { requirement } \\
(\mathbf{m a n}-\mathbf{h} / \mathbf{h a})\end{array}$ & $\begin{array}{c}\text { Cost of } \\
\text { operation } \\
(\mathbf{F} / \mathbf{h a})\end{array}$ \\
\hline \multirow{3}{*}{$\mathbf{4}$} & Mechanically & 34.38 & 0.01270 & 78.77 & 4173.38 \\
\cline { 2 - 6 } & Manually & 31.25 & 0.0065 & 154.32 & 5787 \\
\hline \multirow{2}{*}{5} & Mechanically & 21.88 & 0.01390 & 72 & 3814.36 \\
\cline { 2 - 6 } & Manually & 21.25 & 0.0067 & 149.18 & 5594.25 \\
\hline \multirow{2}{*}{$\mathbf{6}$} & Mechanically & 26.25 & 0.01432 & 69.89 & 3702.71 \\
\cline { 2 - 6 } & Manually & 25.00 & 0.0069 & 144.03 & 5401.13 \\
\hline
\end{tabular}


Table.5 Effect of treatment combinations on dependent parameters for chilli seedlings

\begin{tabular}{|c|c|c|c|c|c|c|c|c|}
\hline $\begin{array}{l}\text { Treatment } \\
\text { combina- } \\
\text { tions }\end{array}$ & $\begin{array}{c}\text { Upright } \\
\text { plants } \\
(\%)\end{array}$ & $\begin{array}{c}\text { Laying } \\
\text { down } \\
\text { plants (\%) }\end{array}$ & $\begin{array}{c}\text { Mortality } \\
(\%)\end{array}$ & $\begin{array}{c}\text { TFC } \\
(\mathbf{h a} / \mathbf{h})\end{array}$ & $\begin{array}{c}\text { EFC } \\
(\mathbf{h a} / \mathbf{h})\end{array}$ & $\begin{array}{c}\text { Field } \\
\text { efficiency } \\
(\%)\end{array}$ & $\begin{array}{c}\text { Labour } \\
\text { requirement } \\
\text { (man-h/ha) }\end{array}$ & $\begin{array}{c}\text { Cost of } \\
\text { operation } \\
\text { (₹ /ha) }\end{array}$ \\
\hline A1B1 & 70 & 30 & 28.75 & 0.01491 & 0.01287 & 86.07 & 77.77 & 4120.13 \\
\hline A1B2 & 67.50 & 32.50 & 40 & 0.01445 & 0.01254 & 86.59 & 79.78 & 4226.63 \\
\hline A2B1 & 75 & 25 & 13.75 & 0.01656 & 0.01403 & 84.64 & 71.32 & 3778.79 \\
\hline A2B2 & 73.75 & 26.25 & 30 & 0.01619 & 0.01377 & 84.78 & 72.67 & 3849.94 \\
\hline A3B1 & 68.75 & 31.25 & 16.25 & 0.01716 & 0.01444 & 83.93 & 69.32 & 3672.74 \\
\hline A3B2 & 66.25 & 33.75 & 36.25 & 0.01682 & 0.01420 & 84.23 & 70.45 & 3732.67 \\
\hline SEM, A & $1.72 *$ & $1.72 *$ & $1.99 *$ & $0.0001 *$ & $0.0001 *$ & $0.14 *$ & $0.54 *$ & $28.43 *$ \\
\hline $\mathbf{C D}, \mathbf{A}$ & 5.17 & 5.17 & 6.00 & 0.0005 & 0.0003 & 0.43 & 1.62 & 85.69 \\
\hline SEM, B & 1.40 & 1.40 & $1.62 *$ & $0.0001 *$ & $0.0001 *$ & $0.12 *$ & $0.44 *$ & $23.21 *$ \\
\hline CD, B & $\mathrm{NS}$ & $\mathrm{NS}$ & 4.90 & 0.0004 & 0.0003 & 0.35 & 1.32 & 69.97 \\
\hline SEM, $\mathbf{A} \times \mathbf{B}$ & 2.43 & 2.43 & 2.81 & 0.0002 & 0.0001 & 0.20 & 0.76 & 40.20 \\
\hline $\mathbf{C D}, \mathbf{A} \times \mathbf{B}$ & $\mathrm{NS}$ & $\mathrm{NS}$ & $\mathrm{NS}$ & NS & NS & $\mathrm{NS}$ & $\mathrm{NS}$ & $\mathrm{NS}$ \\
\hline $\mathrm{CV} \%$ & 6.91 & 16.29 & 20.46 & 2.64 & 2.13 & 0.48 & 2.06 & 2.06 \\
\hline
\end{tabular}

* Significant at 5 per cent level, NS = Non-significant

A: Age of seedling $\left(A_{1}=4\right.$ weeks, $A_{2}=5$ weeks, $A_{3}=6$ weeks $)$

$\mathrm{B}$ : Types of bed $\left(\mathrm{B}_{1}=\right.$ Mulch bed, $\mathrm{B}_{2}=$ Bare bed $)$ 
Fig.1 Conceptual design of vegetable transplanter

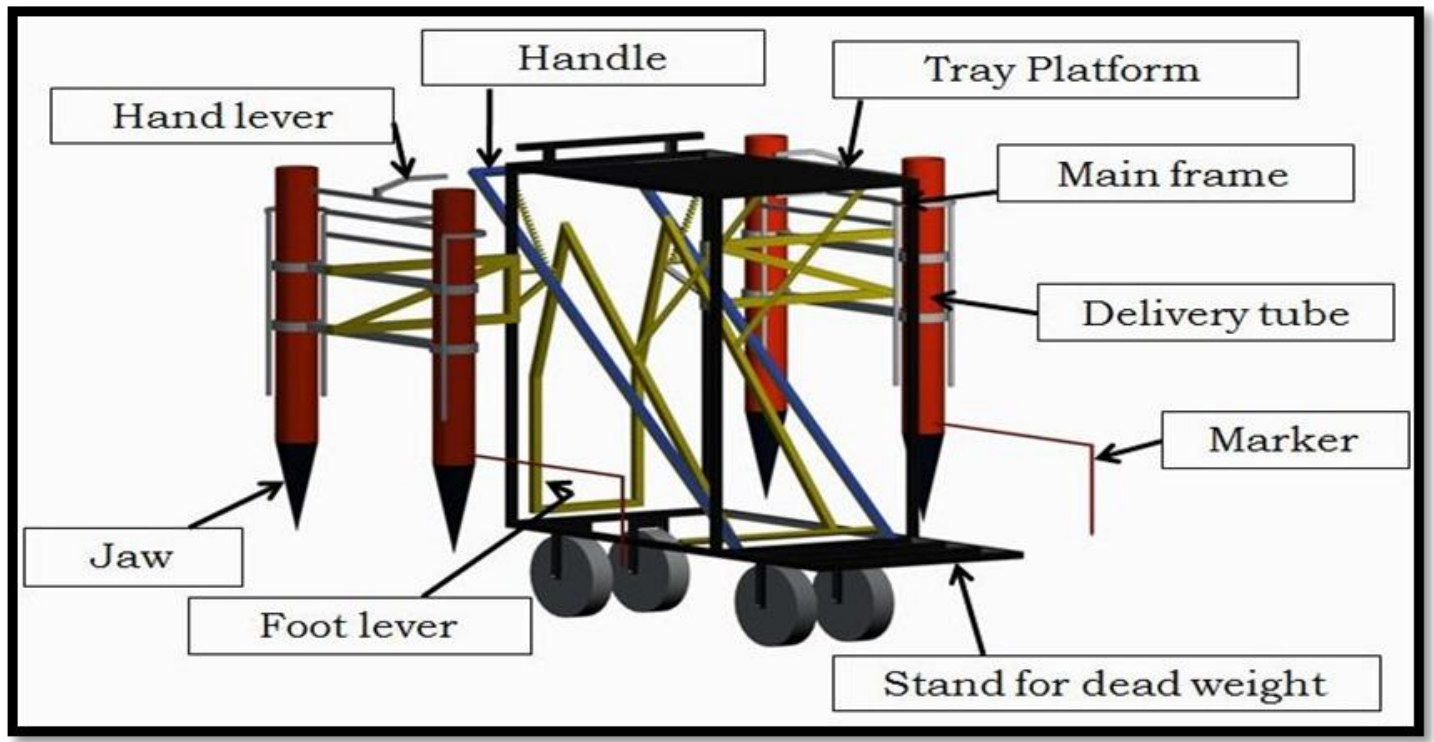

Fig.2 Main frame

Fig.3 Hollow delivery tube
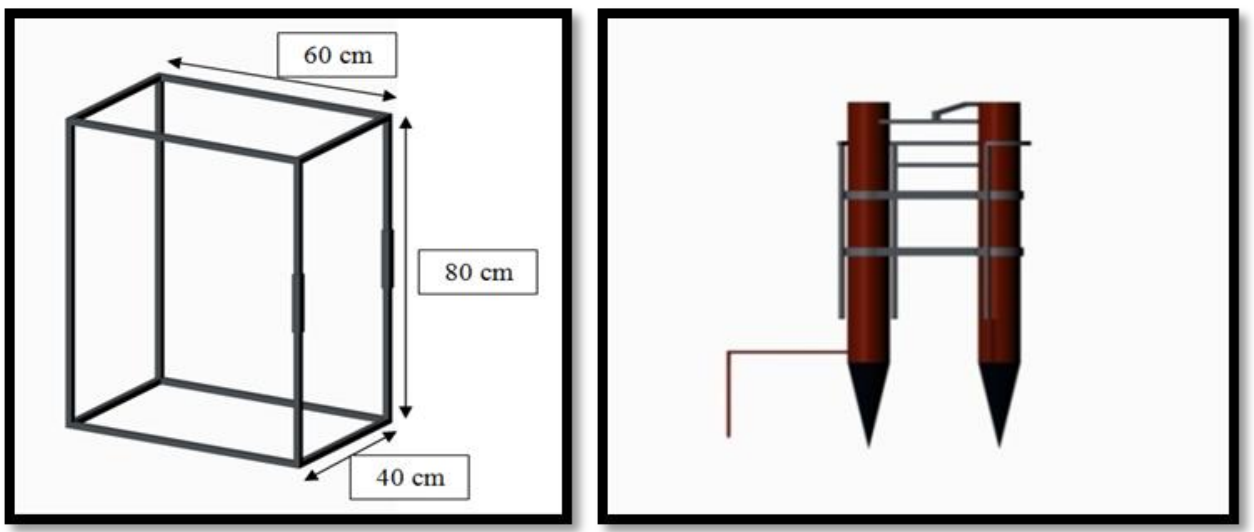

Fig.4 (A) Actuator ring

Fig.4 (B) A side view actuator ring
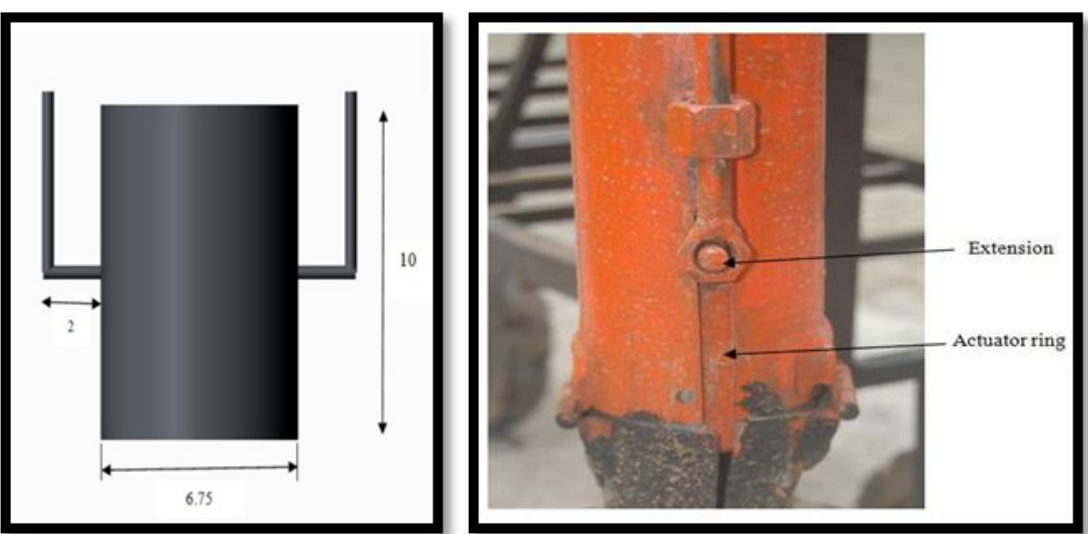
Fig.5 Jaw

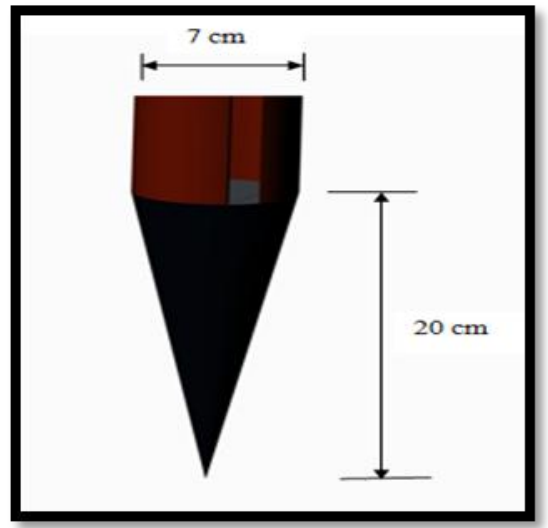

Fig.6 Hand lever

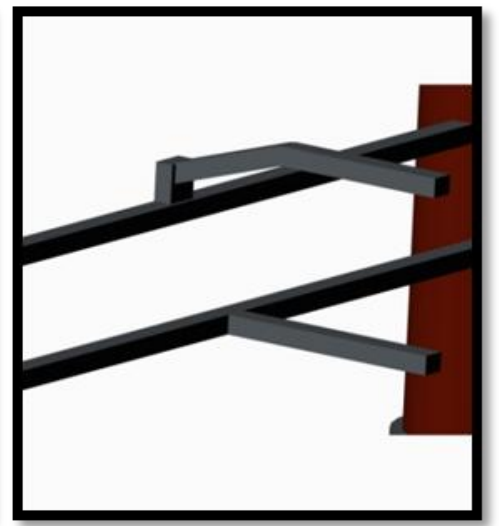

Fig.7 Dead weight stand

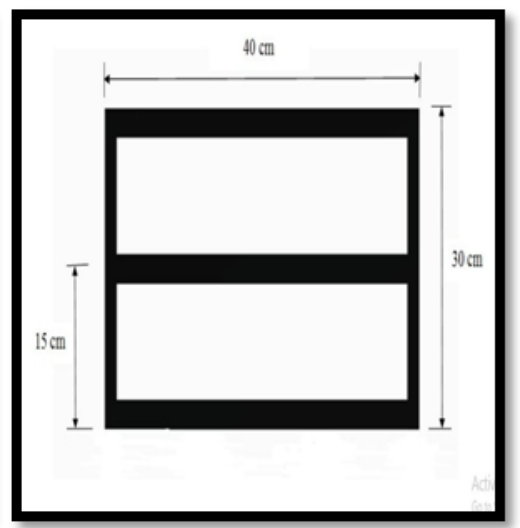

Fig.8 Developed vegetable transplanter
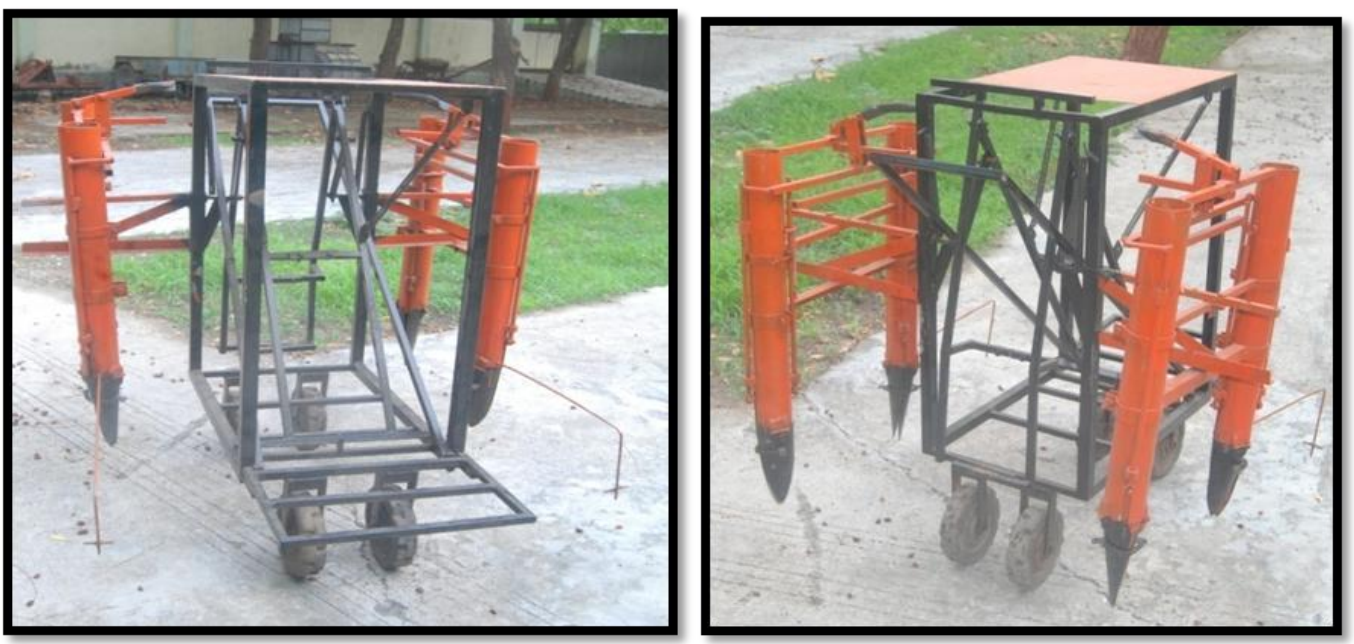

Fig.9 Working of vegetable transplanter

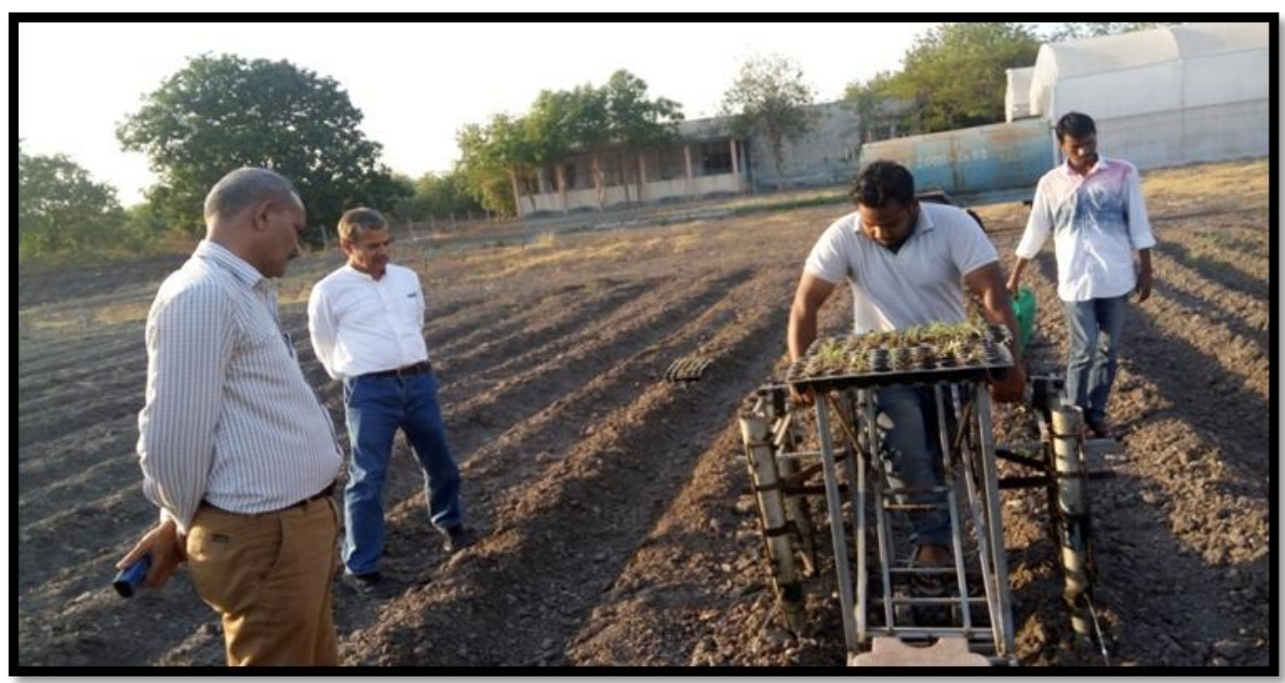


Therefore the effective field capacity, were higher in 6 week seedlings as compared to 5 week and 4 week seedlings. Table 5 shows that the mean effective field capacity for both types of bed was significant. It also shows that on mulch bed, effective field capacity were higher for all the ages of seedlings. The interaction between age of seedling and type of bed on effective field capacity was found non-significant at 5 per cent level of significance. It clearly states that as the age increases the value of effective field capacity increases in both types of beds.

\section{Field efficiency}

The percentage of field efficiency varied from 83.93 to $86.59 \%$. Table 5 shows that the mean field efficiency for all three ages was significant. It also shows that the value of field efficiency was higher at the 4 weeks age of seedlings. The field efficiency is inversely proportional to theoretical field capacity; therefore the field efficiency shows decreasing trend with the increase in age. Table 5 shows that the mean field efficiency for both types of bed was significant. It also shows that on bare bed, field efficiency was higher. The interaction between age of seedling and type of bed on field efficiency was found non-significant at 5 per cent level of significance. Field efficiency in both the type of bed has shown reducing trend with increase in age from 4 to 6 weeks.

\section{Labour requirement}

The values of labour requirement varied from 69.32 to $79.78 \mathrm{man}-\mathrm{h} / \mathrm{ha}$. Table 5 shows that the mean labour requirement for all three ages was significant. It also shows that the value of labour requirement was least at the 6 weeks (69.32 man-h/ha) age of seedlings. Table 5 shows that the mean labour requirement for two types of bed was significant. It also shows that on mulch bed, labour requirement were least. The interaction between age of seedling and type of bed on labour requirement was found non-significant at 5 per cent level. As the age of seedling increases the strength of seedling as well as the bonding of roots and soil is firm, due to which the handling becomes easy and less time consuming. Mean values of labour requirement has shown reducing trend with increase in age of seedlings with least values at 6 weeks of age.

\section{Cost of operation}

The values of cost of operation varied from 3672.74 to 4226.63 ₹ /ha. Table 5 shows that the mean cost of operation for all three ages was significant. It also shows that the value of cost of operation was least at the 6 weeks (3672.74 ₹ /ha) age of seedlings. As the age of seedling increases the strength of seedling as well as the bonding of roots and soil is firm, due to which the handling becomes easy and less time consuming. Cost of operation has shown reducing trend with increase in age of seedling for both types of bed. Table 5 shows that the mean value of cost of operation for two types of bed was significant. It also shows that on mulch bed cost of operation were least. The reason seems to be moisture retains in case of mulch bed was helpful for easy penetration and opening of jaw into the soil. The interaction between age of seedling and type of bed on cost of operation was found non-significant at 5 per cent level of significance.

\section{Observed field parameters}

Soil moisture and bulk density were determined on the dry basis at the time of transplanting.

\section{Comparative field performance}

The developed two-row manually operated vegetable transplanter was compared with manual method for its economic feasibility 
and subsequent acceptability by vegetable growers. Field capacity, plant mortality and cost economics of using the device for the purpose were calculated and are given in Table 4.

The transplanter showed $3.13 \%, 0.63 \%$ and $1.25 \%$ higher mortality as compared to manual transplanting for 4, 5 and 6 week age of seedlings respectively. Similarly the percentage of labour saving was observed as $76 \%, 77 \%$ and $75 \%$ also the time saving of $62 \%, 72 \%$ and $74 \%$ was observed in transplanter as compared to manual transplanting for 4,5 and 6 week age of seedlings respectively. The cost of operation was found to be higher by $16.14 \%, 17.80 \%$ and $16.99 \%$ in case of manual transplanting as compared to developed transplanter for 4,5 and 6 week age of seedlings respectively.

\section{Cost economics of the developed vegetable transplanter}

The cost of transplanting seedling with vegetable transplanter was calculated and compared with the cost of manual transplanting. The total cost of operation was determined based on total fixed cost and variable costs. The total cost of developed transplanter was worked out to be ₹ 18,000 . Capacity of transplanting seedlings manually and with vegetable transplanter was found to be 240 seedlings/h and 463 seedlings/h, respectively.

The cost of manual transplanting was found to be ₹ 156.38 per 1000 seedlings. The total cost of transplanting 1000 seedlings using the vegetable transplanter was found to be ₹ 114.43. Thus a total saving of ₹ 41.95 per 1000 seedlings could be achieved for transplanting operation with vegetable transplanter. The payback usage in terms of number of seedlings transplanting was found to be $4,29,082$ seedlings. The payback period was found to be 926.74 hours or 3.71 year of operation of the vegetable transplanter, which was 37.07 per cent of its total expected life.

The age of seedling showed significant results and type of bed individually and in combination showed non-significant results at 5 per cent level considering upright plants, laying down plants and plant mortality as parameters for chilli seedling. Theoretical field capacity, effective field capacity, field efficiency, labour requirement and cost of operation for age of seedling and type of bed individually showed significant results and in combination showed non-significant results at 5 per cent level for chilli seedling.

Maximum upright plants were found as $75 \%$, minimum laying down plants as $25 \%$ and minimum plant mortality as $13.75 \%$ with 5 weeks age of seedlings on mulch bed. Maximum theoretical field capacity was found as $0.01716 \mathrm{ha} / \mathrm{h}$, maximum effective field capacity was found as $0.01444 \mathrm{ha} / \mathrm{h}$, minimum labour requirement was found as $69.32 \mathrm{man}-\mathrm{h} / \mathrm{ha}$ and minimum cost of operation was found as 3672.74 ₹/ha with 6 weeks age of seedlings on mulch bed.

Maximum field efficiency was found as 86.75 $\%$ with 4 weeks age of seedlings on bare bed. The saving on transplanting cost by using the developed transplanter when compared with manual transplanting was found to be ₹ 41.95 per 1000 seedling transplanting. The payback period was found to be 926.74 hours or 3.71 year of operation of the vegetable transplanter.

\section{References}

Boa, W. (1984). The design and performance of an automatic transplanter for field vegetables. J. Agric. Engg. Res. 30:123130.

Choudhury D., Singh, V. V. and Dubey, A. K. 
(2001). Refinement and adopting mechanical vegetable transplanters for Indian conditions. Paper presented in 35th Annual Convection of ISAE held at College of Agricultural Engineering and Technology, OUAT, Bhubaneshwar (Orissa), India.

Choudhury, D.; Singh, V. V. and Dubey, A. K. (1997). Survey on existing status of seedling-planting method and determination of mechanization need of planting for important vegetable crops in India, C.I.A.E., Annual Report, pp: 4-
7.

Patil, A. S., Davane, S. S. and Malunjkar, S. V. (2015). Design, Development and Testing of Hand Held Vegetable Transplanter. International Journal of Advanced Research, 3(1): 247-253.

Satpathy, S. K., and Garg, I. K. (2008). Effect of Selected Parameters on the Performance of a Semi-automatic Vegetable Transplanter. Agricultural mechanization in Asia, Africa, and Latin America, 39(2):47-51.

\section{How to cite this article:}

Thorat Pankaj, V., K.B. Jhala and Jadhav Mahesh, L. 2017. Design, Development and Performance Evaluation of Manually Operated Two Row Trolley Type Vegetable Transplanter. Int.J.Curr.Microbiol.App.Sci. 6(11): 3577-3589. doi: https://doi.org/10.20546/ijcmas.2017.611.420 